\title{
Proposal of a web application of virtual letters for restaurants as a prevention measure in time of covid-19
}

\author{
Propuesta de una aplicación web de cartas virtuales para restaurantes como medida de \\ prevención en tiempos de covid-19
}

\author{
Jose Antonio Ogosi Auqui ${ }^{1}$, (D) Angel Salazar Garcia ${ }^{1}$, (D) Jose Garcia Cuzcano ${ }^{1}$, iD Sebastian Parra \\ Cabanillas ${ }^{1}$, AD Andrés Feria Ramos ${ }^{1}$ \\ ${ }^{1}$ Universidad Nacional Federico Villareal
}

\begin{abstract}
The COVID - 19 pandemic and the health crisis that today has affected the entire world, has forced many companies to make the use of technological tools essential for them to compete in the market. All this has made mobile applications or web systems the most appropriate solution to implement in your business model. The present investigative work aims to propose the analysis and development of an order management system, digitizing the menu for restaurants and allowing the ordering process to be quick and interactive. Following the guidelines provided by the Government of Peru, in which they recommend, the digitization of traditional letters as it is considered a source of the spread of the coronavirus and to be replaced by menus or virtual letters which can be scanned through QR codes. The development of this project allows customers to view in detail the available dishes offered by the restaurant and proceed to order the food they want, on the other hand, the restaurant can keep track of all orders and relevant information about the business. To develop the prototype, an analysis and information gathering of the technologies to be implemented will begin.
\end{abstract}

Keywords: restaurants, web systems, digital menus, QR codes, prevention, COVID - 19.

\section{Resumen}

La pandemia del COVID - 19 y la crisis sanitaria que hoy en día ha afectado a todo el mundo, ha obligado a muchas empresas que el uso de las herramientas tecnológicas sea indispensable para que puedan competir en el mercado. Todo esto ha hecho que las aplicaciones móviles o los sistemas web sean la solución más adecuada a implementarse en su modelo de negocio. El presente trabajo investigativo tiene como finalidad proponer el análisis y desarrollo de un sistema de gestión de pedidos, digitalizando la carta para restaurantes y permitir que el proceso de pedidos sea de forma rápida e interactiva. Siguiendo los lineamientos brindados por el Gobierno del Perú, en la cual recomiendan, la digitalización de las cartas tradicionales por considerarse un foco de propagación del coronavirus y ser sustituidos por menús o cartas virtuales las cuales puedan escanearse a través de códigos QR. El desarrollo de este proyecto permite a los clientes visualizar a detalle los platillos disponibles que ofrece el restaurante y proceder a ordenar la comida que deseen, por otro lado, el restaurante puede llevar un control de todas las órdenes y sobre la información relevante del negocio. Para desarrollar el prototipo se comenzará con un análisis y levantamiento de información de las tecnologías que se implementarán.

Keywords: restaurantes, sistemas web, menús digitales, códigos QR, prevención, COVID - 19. 


\section{Introduction}

Today the use of technologies has spread greatly in the industry, since this represents an opportunity for improvement for any type of business because it enhances the effectiveness of its processes (Jaime et al., 2014). However, (Nhamo et al., 2020) tells us that the pandemic caused by COVID - 19 has greatly affected the tourism and gastronomy industries, since these types of businesses are susceptible to natural disasters because they affect the infrastructure and also to any situation that affects human movement, particularly if it is an outbreak of a pandemic such as the one that occurred in 2020. Similarly, it mentions that Ministerial Standard No. 822-2018MINSA must be complied with, where the "Sanitary Standard for the Operation of Restaurants and Related Services" is ratified, which indicates all the preventive measures that must be taken by both the restaurant and the customer.

Measures that range from complying with the policies of not having contact during the service, disinfection, the use of an application that serves as a means of contact and that the sale is made digitally.It is a way of reinventing themselves that must be chosen by restaurants that have not yet done so (Bernal \& Artunduaga, 2020). That is why the performance of delivery applications is of the utmost importance, since due to their characteristics they allow the restaurant to offer a good service and, at the same time, comply with the preventive measures of COVID-19 (Silipo et al., 2020).

Likewise, customer demand is increasing, so it is necessary for restaurants to opt for this type of solutions to return to the market and be competitive with the rest, he mentions (Nhamo, Dube, Chikodzi, 2020). Therefore, it can be said that from now on the new normal radically changed the traditional business model in restaurants. Encouraging the implementation and use of new digital tools in your business process.
That is why, through this article, the purpose of this article is to identify the incidence generated by the use of this digital tool in restaurants as a preventive measure in contact with the pandemic that we are experiencing.

Also, this article will explain the technical terms for the design, Nowadays organizations, due to the contextual situation, have found it necessary to reinvent their business so that it can cope with the health crisis and for this they must adapt to all safety protocols, respecting health regulations.

Therefore, companies have increasingly made use of technological tools, in which through innovative proposals they can adapt their businesses, so that they benefit their customers and can continue as they previously carried out their activities with greater profits.

Research question statement: How will the proposal to implement a virtual menu web application for restaurants have an impact as a preventive measure in times of covid-19? Developing a prototype of a web application that replaces the conventional menus or menus of restaurants, supported by the opinions of end users to obtain a product in which information on the dishes offered is known, investigated and interacted with.

- Investigate the impact of the web application regarding the reduction of contact between people within the restaurant as a preventive measure against COVID - 19.

- A virtual menu will help restaurants to cope with the health crisis that is being experienced in order to comply with the measures implemented by the Government.

- Identify the appropriate tools to develop the web application complying with the necessary requirements and making it understandable for all types of audiences. 
- Deliver a web application that allows diners to have more detailed information about each dish that will be offered within the restaurant.

\section{Materials and methods Methodology}

The type of research of this project is applied with

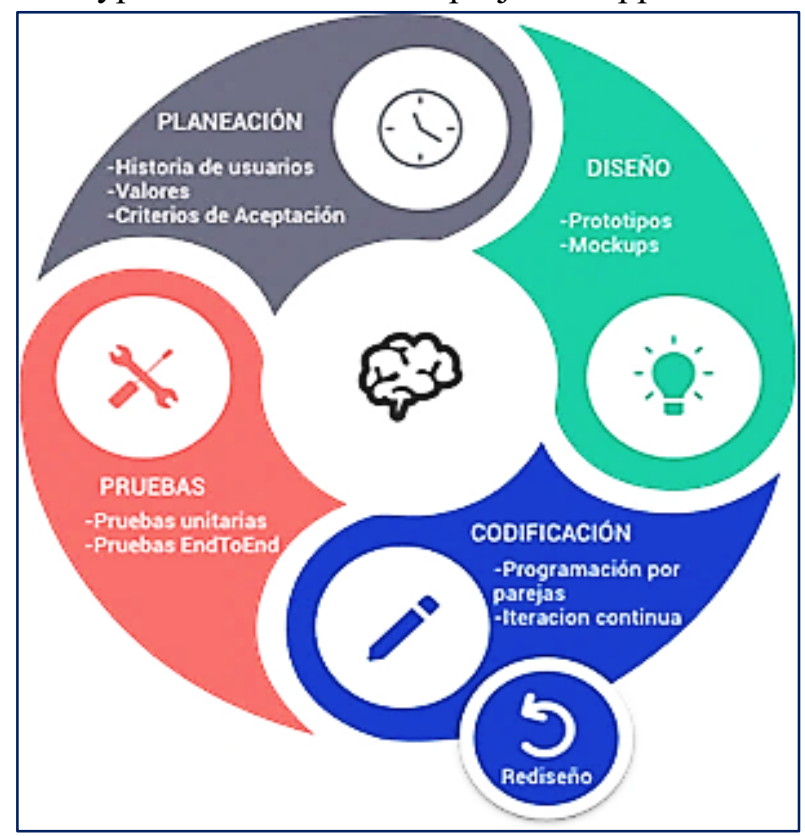

a descriptive design, which aims to specify the impact of the implementation of a virtual menu system for restaurants.

For software development, the XP methodology was used as a basis, which is an agile software development methodology developed by Kent Beck in 1996, which is based on a set of values that guide development.

This methodology is based on the values of simplicity, communication, feedback and value. XP greatly seeks customer satisfaction (Anwer et al., 2017).

Prototype development: It can be considered as that process of development of a device or system that reveals the viability of a treatment proposal to a problem.

Typically, prototypes are handled only by their designers or by those who understand their underlying technology (Reiser and Anbar, 1984).
The conception takes place on a prototype, in other words, a model or the trial version of the product. Later, after different iterations, the prototype is improved and refined into the finished product (Thomas, 1993).

Balsamiq Mockups: It is a program in which you can design all kinds ofprototypes and sketches that will be useful for the development of a project that is as close as possible to our designed prototype. Likewise, the easy-to-use interface allows you to select between different predesigned models: status bars, menus, progress bars, among others.

Extreme Programming (XP): XP consists of a series of activities, also called life cycle, which is displayed below:

Fig. 1. Life cycle of the XP methodology

Source: Canazaca \& Mamani (2020). Delivery system in times of covid- 19 .

The phases of the XP Methodology are described below.

- Planning, in this phase the system requirements are identified.

- Design, in this phase it is explained how the sketch will be, it is not necessary to show the structure or functionalities.

- Coding, in this phase the completion of the pending activities for the elaboration of the system is detailed taking into account the user's requirements.

- checkIn this phase, those activities prior to implementation are verified. Unit tests must pass tests before being implemented. There are also the acceptance tests, which consists of the deliverables satisfying the previously agreed upon user requirements.

Variables: In search of developing the problem raised in the introduction, the operationalization of the 2 variables indications in the research topic was developed:

- Independent variable: web application

- Dependent variable: virtual menus for restaurants 
Table 1.

Operationalization of the independent variable: web application

\begin{tabular}{|c|c|c|}
\hline Independent Variable & Dimensions & Indicators \\
\hline \multirow{4}{*}{ Web application } & - $\quad$ Functionality & $\begin{array}{ll}- & \text { Applicability } \\
- & \text { Accuracy } \\
- & \text { Interoperability security }\end{array}$ \\
\hline & - $\quad$ Reliability & $\begin{array}{ll}\text { - } & \text { Resilience } \\
\text { - } & \text { Fault tolerance }\end{array}$ \\
\hline & - Usability & $\begin{array}{ll}\text { - } & \text { Ability to be understood } \\
\text { - } & \text { Ability to be operated } \\
\text { - } & \text { Ability to be learned }\end{array}$ \\
\hline & - $\quad$ Portability & $\begin{array}{ll}\text { - } & \text { Ability to be replaced } \\
\text { - } & \text { Ease of installation }\end{array}$ \\
\hline
\end{tabular}

Table 2.

Independent variable questionnaire: web application

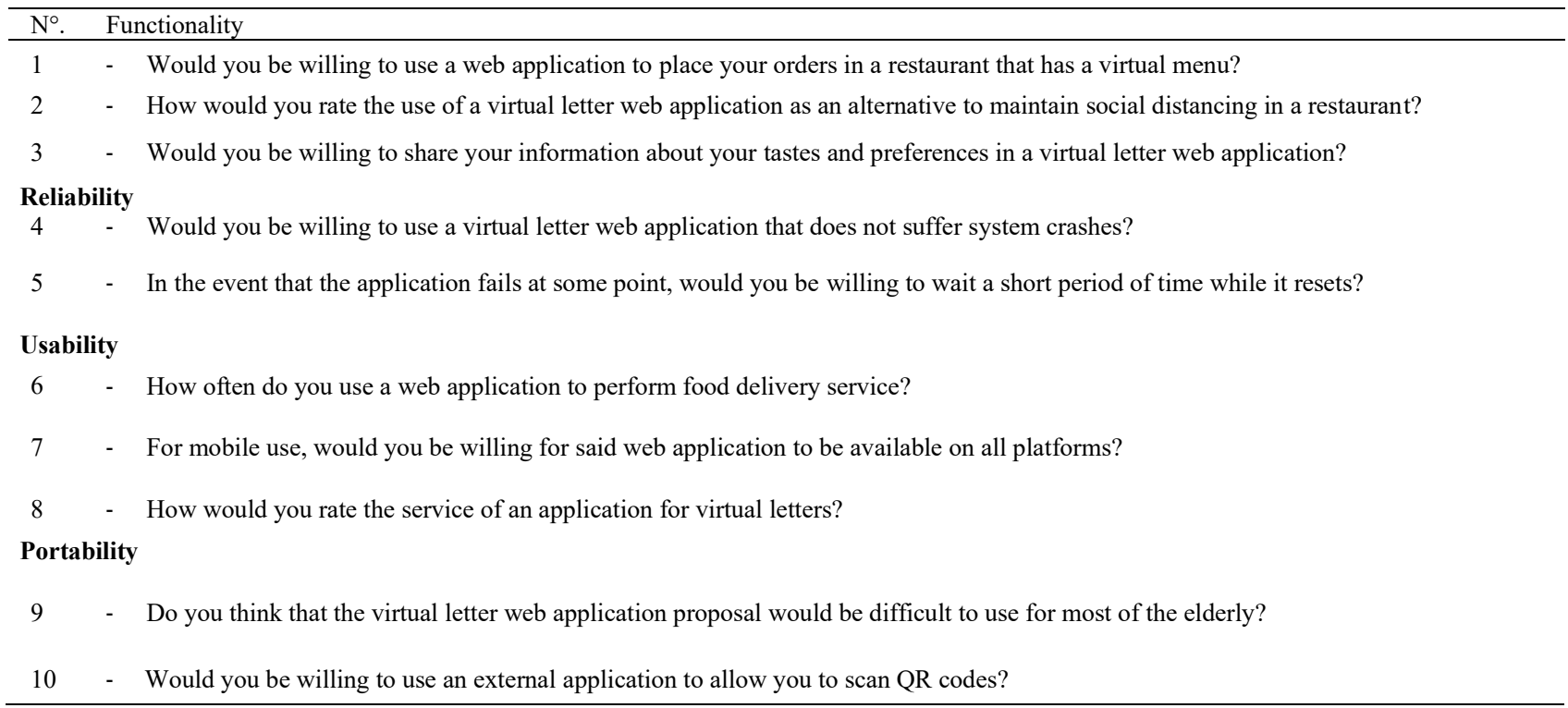

Table 3.

Operationalization of the dependent variable: virtual

Dependent variable

Dimensions

Virtual letters for restaurants

Virtual letters from the client
- Implementation benefit

- Efficiency and automation

- $\quad$ Easy to use

- Better shopping experience

- Greater interaction 
Table 4.

Dependent variable questionnaire: virtual letters for restaurants

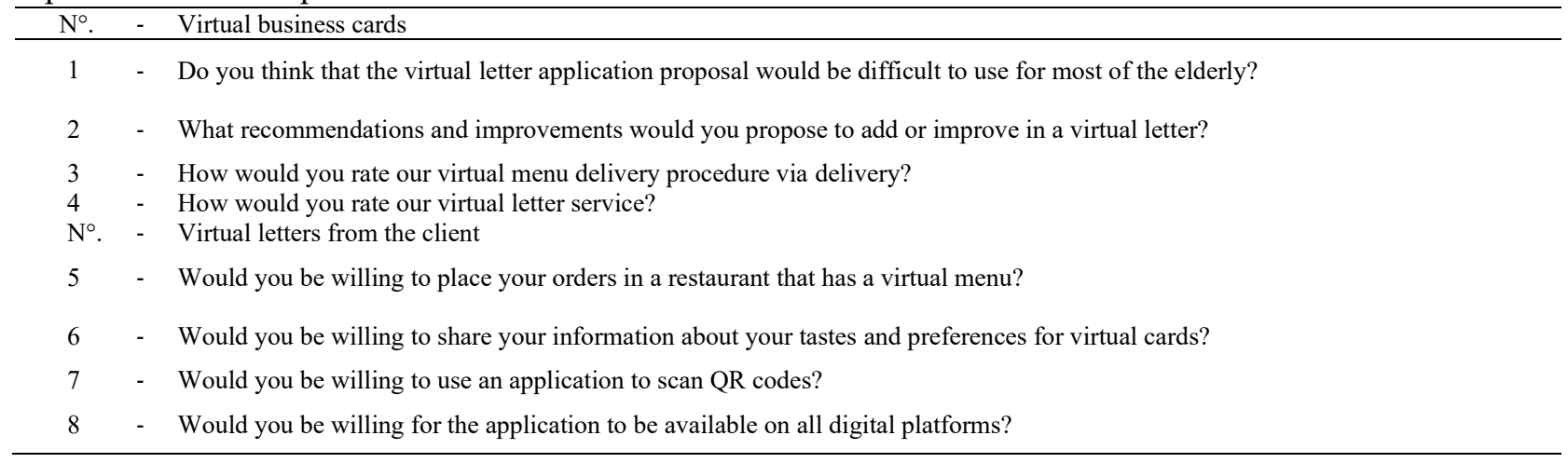

\section{Architecture design:}

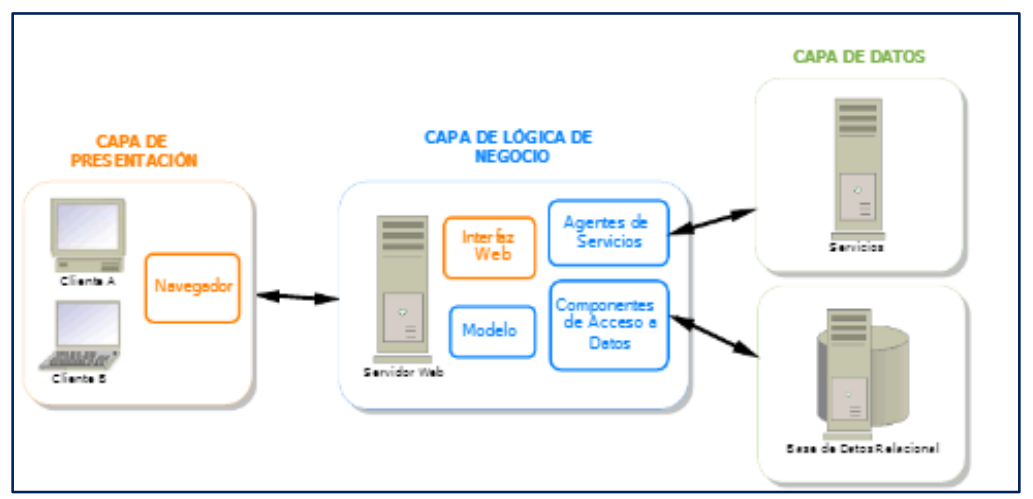

Fig. 2. Layer architecture of the web application

Source: self made

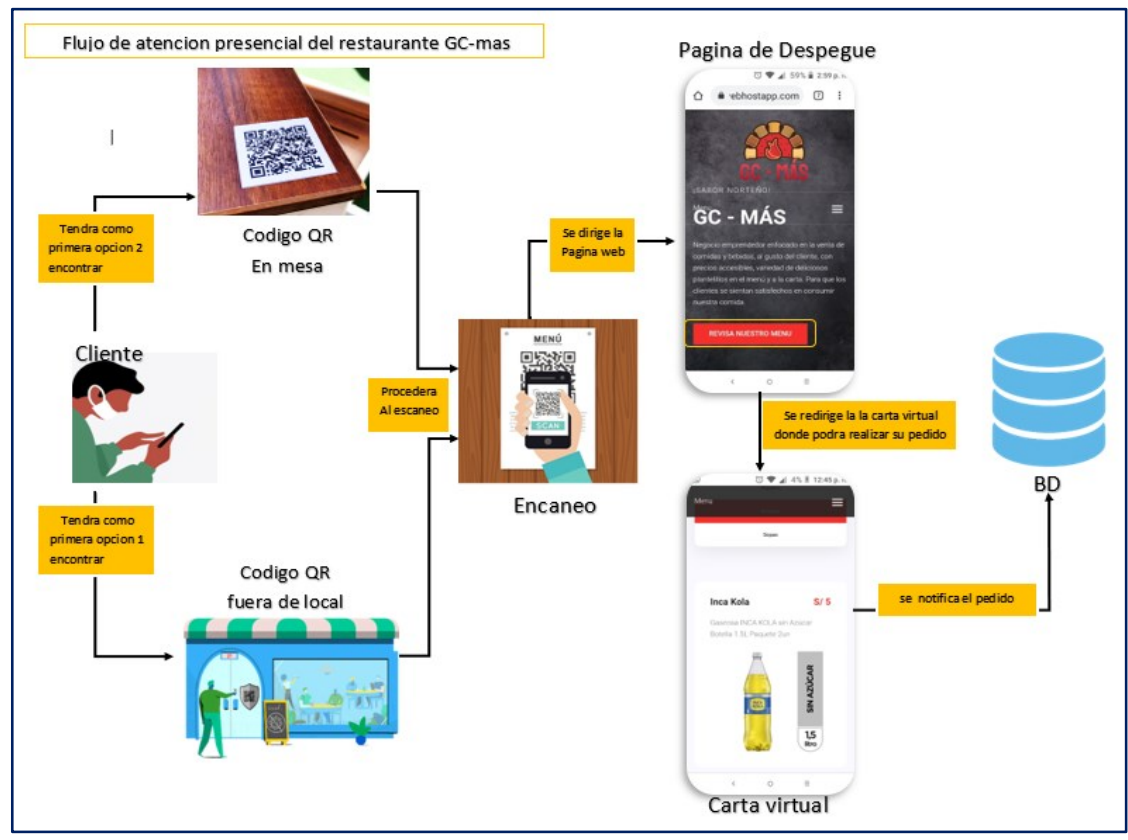

Fig. 3. Process flow of the virtual chart architecture

Source: self made 
Balsamiq Mockups Design: For the design of the prototypes, it was decided to use Balsamiq Mockups, in which the functionalities of the web application of virtual menus for restaurants were designed in the time of Covid-19.

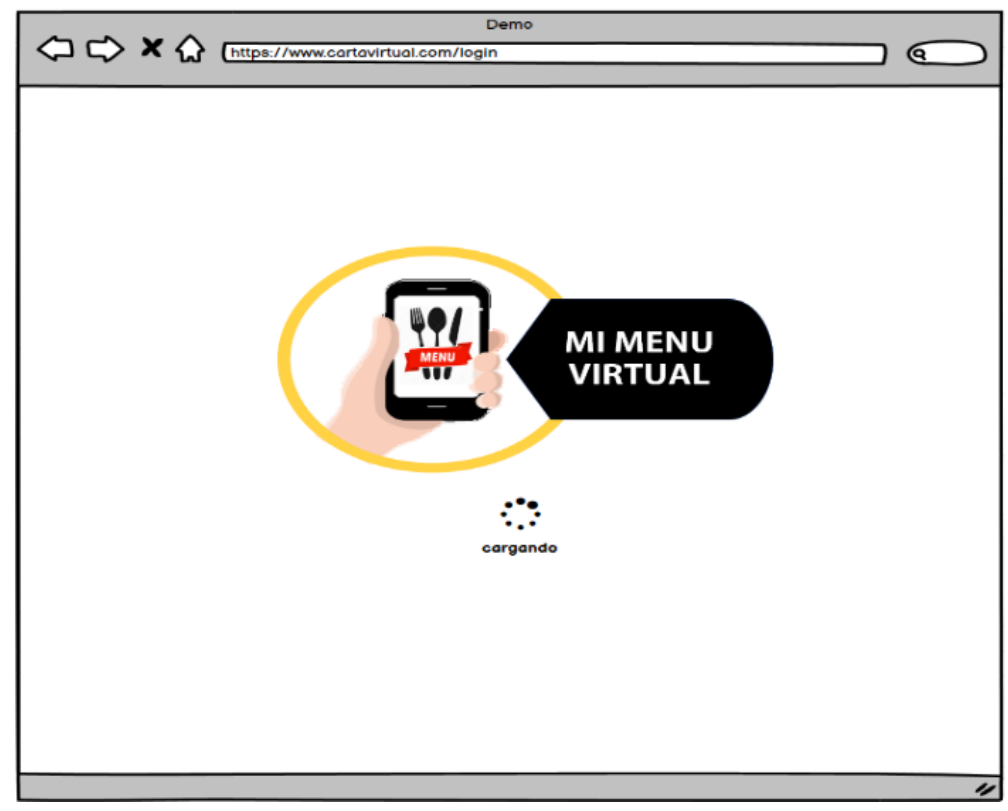

Fig. 4. Prototype: Login to the system

Source: self made

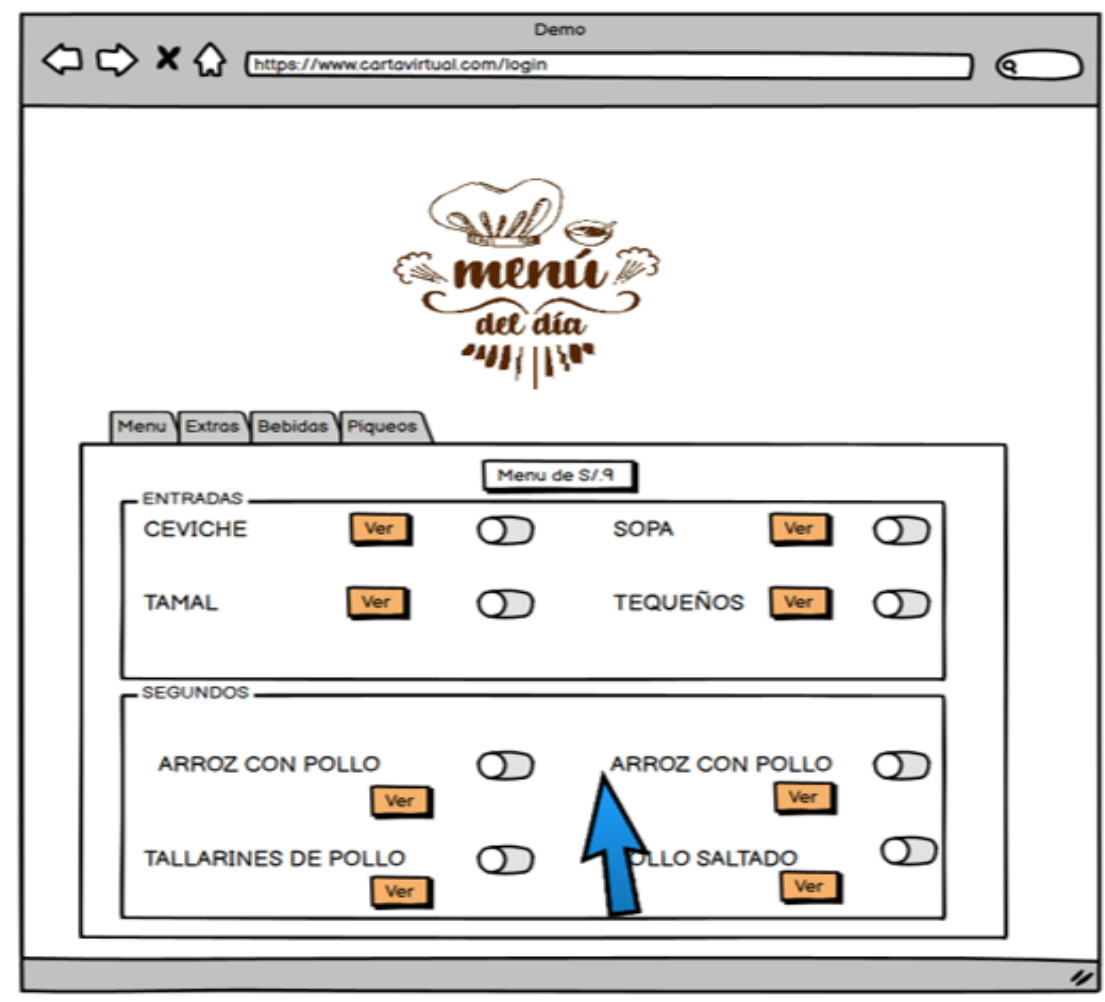

Fig. 5. Prototype: Main menu

Source: self made

Universidad Nacional Intercultural de la Selva Central "Juan Santos Atahualpa" 


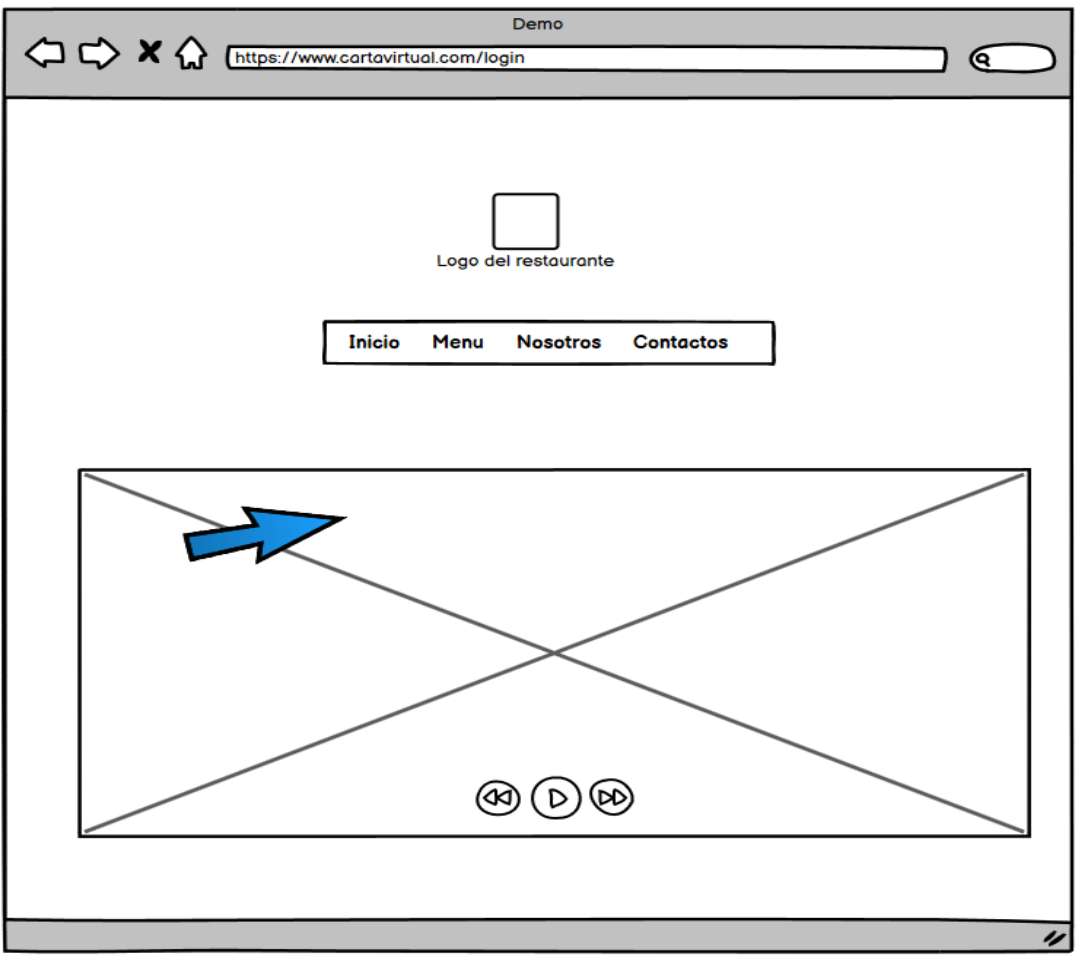

Fig. 6. Prototype: Virtual cards menu

Source: self made

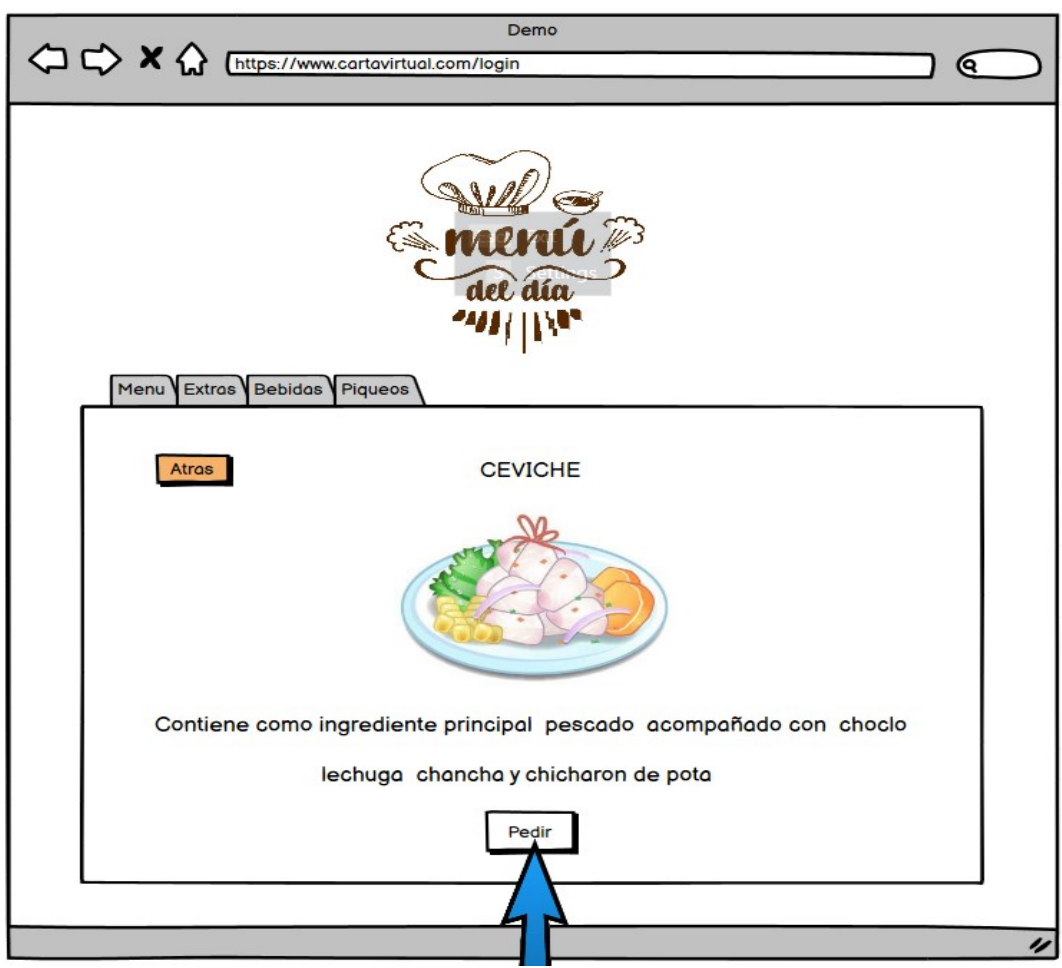

Fig. 7. Prototype: Virtual menu specifications

Source: self made 


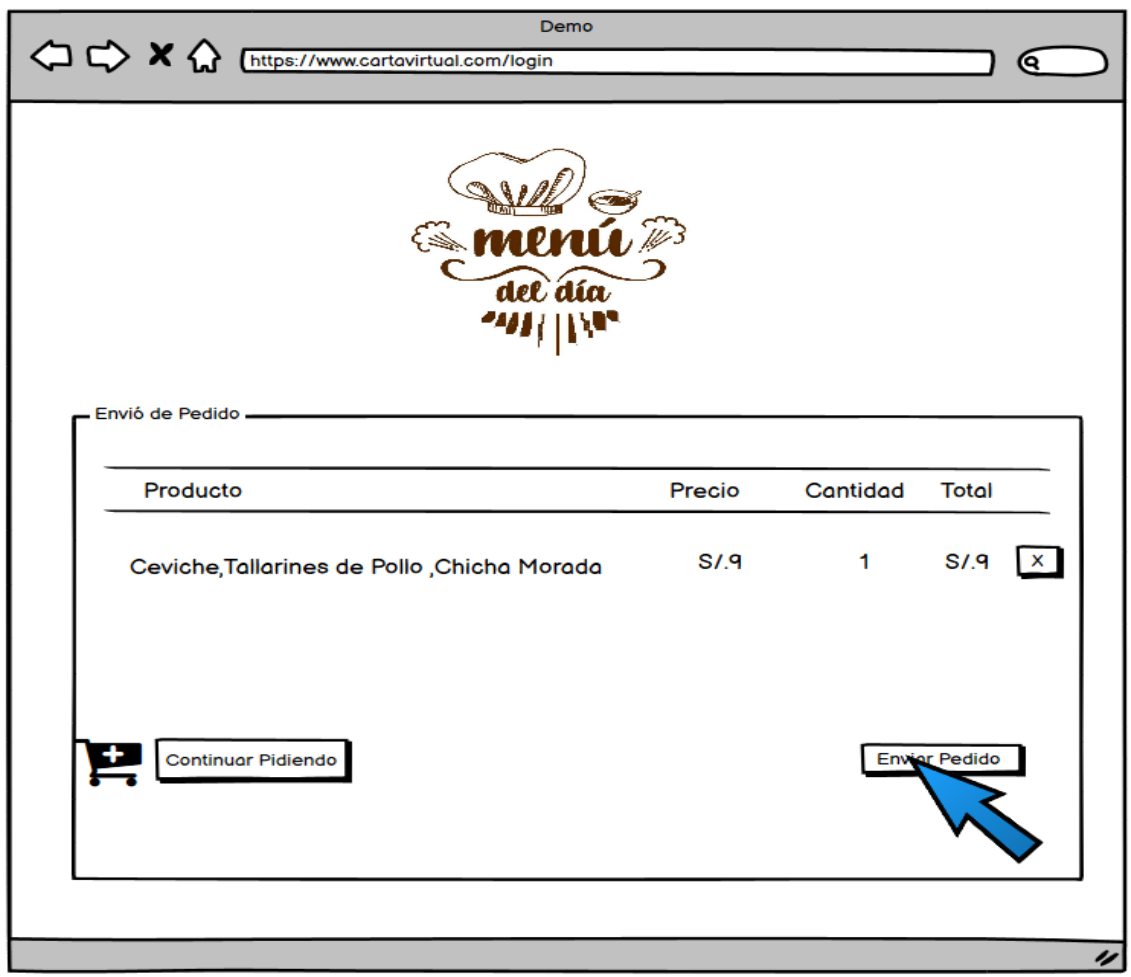

Fig. 8. Prototype: Order shipping detail

Source: self made

\section{Results}

Develop a prototype of a web application that replaces the conventional menus of restaurants, supported by the opinions of end users to obtain a product in which information on the dishes offered is known, investigated and interacted with.

- A prototype can be developed on a web application since it is the best option for both diners and for the restaurant, since detailed and precise information will be provided on each dish that will be offered, each update, offers, discounts, etc., will be updated in real time within the application, as well as taking care of the health of diners and restaurant workers, contact between the two will be avoided parties, the established health measures will be respected.

- All this will be achieved thanks to the opinions collected from end users obtaining a product that meets standards established and helps reduce the spread of COVID - 19, avoiding more risks of contagion.

- The application will be friendly and understandable for all audiences, easy to use and excellently executed to meet customer expectations such as the restaurant's requirements.

Investigate the impact of the web application regarding the reduction of contact between people within the restaurant as a preventive measure against COVID - 19.

- Due to the health crisis in which all countries find themselves, digitization will be part of the new normal in the world if consumption is concerned. The use of technology as a means to develop web systems or applications that functions through $\mathrm{QR}$ codes takes more strength in the midst of all this crisis, so the food industry must comply with all current hygienic measures.

- For this reason, it helps in a great way since when developing a web application it will be possible to digitize the traditional letters, users 
will be able to see it through their mobile phone, in a detailed way, with the ingredients and prices of each dish that is offered. This will greatly contribute to the diners avoiding passing the traditional menu from hand to hand, and on the other hand, that the waiter has the sole responsibility of taking the food plates to the respective tables, by means of a tray, without having contact with the dishes, complying with the measures implemented by the government, such as the use of gloves, masks and face shields.

A virtual menu will help restaurants to cope with the health crisis that is being experienced in order to comply with the measures implemented by the Government.

- A virtual menu will help restaurants to comply with all the regulations established by Ministerial Resolution No. 822-2018-MINSA and thus combat the entire crisis that the country is experiencing, in this way it will be possible to avoid physical contact between diners and the restaurant, thus contributing to the country in avoiding the contagion of the coronavirus, and being able to reduce the coronavirus health crisis that is occurring in all countries, it will also attract new customers who are also willing to fight the covid-19

Deliver a web application that allows diners to have more detailed information about each dish that will be offered within the restaurant.

- The web application, in addition to being dynamic and contributing to the reduction of the spread of the virus and the crisis that is occurring in all countries, will help restaurants to have a better organization of the data on their dishes to offer to diners. The restaurant will be able to better manage all the orders during the day, it will take better control of all the customers who enter, identifying their preferences and tastes, in this way it will be possible to implement new dishes related to the tastes of the customers. With all this information, the company will be able to make better decision-making regarding its strategies to benefit its customers.

\section{Conclusion}

- This project reflects the impact of IT on an organization, in this case a restaurant, in order for it to continue with its activities in this difficult situation that we are experiencing, Also, in the improvement of its internal processes, which will allow take better control of information.

- This proposal, while particularly suited to one company, can be useful as a model for other restaurant companies similar in nature to conventional restaurants. The most relevant components to guarantee the success of this type of proposal is to have the collaboration of the business owners; in the same way, have the essential tools to deal with the matter in question.

- Also, the project carried out helps to stand out from the health crisis facing the country since the food sector has been severely hit, and to bring the future of the organization to the great technological change that the new technological era means.

\section{References}

[1] Bermudez, D. \& Guzman, I. "Mobile application based on augmented reality to view the menu of a restaurant". July 2016.

[2] Campos, R. "Virtual restaurant menu using AR augmented reality". March 2019.

[3] Braña, A. "Digital menu for Teppanyaki restaurant". June 2019.

[4] Costa, G. \& Vallejos, D. "Study of usability and user experience of digital menu for restaurants". December 2018.

[5] Zambrano, S., Bolaños, F. \& Gierbolini F. "Feasibility study for the creation of a restaurant dedicated to seafood, with the implementation of an electronic menu in the city of Santiago de Cali." February 2015.

[6] Chen, D. \& Villa, G. "Tactile menu for restaurants." October 2013. 
[7] Beck, J. "Virtual menu for restaurants." December 2017.

[8] Ventura, J. "Interactive bar-restaurant menu system." August 2015.

[9] Mendoza, L. \& Piñón, M. "Usability of QR Menus: Addressing the recommendations against covid-19". September 2020.

[10] Mishra, B., Choudhary, B. \& Bakshi, T. "Touch digital ordering system on Android using GSM and Bluetooth for restaurants". April 2015.

[11] Gunawardena, D. \& Sarathchandra, K. "BestDish: A digital menu and food recommendation system for restaurants in the hospitality industry." International Conference on Image Processing and Robotics (ICIP) ". June 2020.

[12] Cheong, S., Chiew, W. \& Yap, W. "Design and development of Multitouch e-restaurant Management System". March 2010.

[13] Ravi, RV, NR, A., E, A., P., H. \& T., J. "An Android-based restaurant automation system with a touch screen." July 2019.

[14] Cañazaca, Y. \& Mamani, J. "Delivery System in times of COVID-2019". December 2020.

[15] Martin, R. "Digital letters: Creativity and security against COVID-19 for restaurants". May 2020.

[16] Muños, M. "Development of an application for making reservations and taking orders at the LongHord restaurant". November 2017.

[17] González, D. "Content manager and access to a web menu via smartphone and tablet by means of QR codes". February 2015.

[18] Nacipucha, L. \& Plua, S. "Development of the prototype of an Android mobile application that allows seat reservations in the WAFFLES AND SUBS restaurant". March 2018.

[19] Suarez, E. \& Ramos, C. "Design of a web platform and a mobile application for the administration and generation of orders in the restaurants of the municipality of Planet Rica Córdoba." April 2015

[20] Pacheco, C. \& Conde, I. "Challenges and opportunities for the gastronomic sector: a call to reinvent its business model”. May 2020.D.
B. Payne and J. R. Stern, "Wavelengthswitched pas- sively coupled single-mode optical network," in Proc. IOOC-ECOC, Boston, MA, USA, 1985, pp. 585-590.

\section{Correspondence}

\author{
Jose Antonio Ogosi Auqui \\ jogosi@unfv.edu.pe
}

